\title{
CLIMATE CHANGE PERCEPTIONS AND ADAPTIVE ACTIONS BY PASTORAL COMMUNITY ON THE TIBETAN PLATEAU, CHINA
}

\author{
SHARIF, J. ${ }^{1}$ - RAFIQ, M. K. ${ }^{2,3}$ - RAFIQ, M. T. ${ }^{4}-$ AZIZ, R..${ }^{5,}{ }^{*}$ - QAYYUM, A. ${ }^{6}$-SALEEM, A.R. ${ }^{7}-$ \\ NISA,W.U. ${ }^{5}-$ JENKS, M. A. ${ }^{8}-$ LI, Y. ${ }^{*}$ \\ ${ }^{I}$ School of Philosophy and Sociology, Lanzhou University, Lanzhou 730000, PR China \\ ${ }^{2}$ UK Biochar Research Center of Geosciences, The University of Edinburgh, Edinburgh EH9 3FF, UK \\ ${ }^{3}$ Rangeland Research Institute, National Agricultural Research Center, 44000 Islamabad, Pakistan \\ ${ }^{4}$ Center for Integrated Research in Basic Sciences, International Islamic University, 44000 Islamabad, \\ Pakistan \\ ${ }^{5}$ Department of Environmental Science, International Islamic University, 44000 Islamabad, Pakistan \\ ${ }^{6}$ Department of Agronomy, University of Haripur, 22620 Haripur, Pakistan \\ ${ }^{7}$ Department of Earth and Environmental Sciences, Bahria University, 44000 Islamabad, Pakistan \\ ${ }^{8}$ School of Plant Sciences, University of Arizona, Forbes Building, Tucson AZ 85721-0036, USA \\ *Corresponding authors \\ e-mail: rukhsanda.aziz@iiu.edu.pk, liyongjin@lzu.edu.cn \\ (Received $9^{\text {th }}$ Dec 2018; accepted $10^{\text {th }}$ Apr 2019)
}

\begin{abstract}
Tibetan plateau is an area of global ecological and cultural significance often called the third pole of the earth, world water towers and roof of the world. The plateau provides forage to $95 \%$ of world's total yak population and supports the largest pastoral population (9.8 million) of the globe. The plateau is vulnerable to climate change which threatens grassland resources, watersheds, livestock and pastoral population. As the pastoralists are the key custodians of the plateau, this study examined their climate change perceptions and analyzed their adaptation strategies in Tibetan Plateau, China. The results showed that majority of the pastoralists were aware of the climate change issues in the plateau. It was found that pastoralists have noticed changes in climate variability leading to grassland degradation and poor animal health and productivity. TV Programs about climate change and weather forecast programs were among the key tools for developing pastoral perception about climate change. The demographic characteristic of the pastorals like education, age and household size proved to contribute in the development of climate change perceptions among pastorals $(\mathrm{P} \leq 0.05)$. The study found that livelihood diversification, having mixed livestock breeds, cultivation of high yielding and drought tolerant forage varieties, grassland fencing and controlled grazing were among the most practiced adaptation strategies in the Plateau. Pastoralists are the key stakeholders of the Plateau. Therefore, their capacity needs improvement to adapt climate effects and work with the government institutions for the betterment of the plateau and their improved livelihood so that it can create win-win situation for pastoralists and government managers as well.
\end{abstract}

Keywords: global warming, climatic variability, pasture utilization, mitigation measures, diversification

\section{Introduction}

Global warming is changing climate rapidly, with adverse effects of excessive and uneven rainfall, floods and droughts with impacts on forests, environment, agriculture and humanity. Therefore, climate change is thought as one of the major threats to the earth's environment and to human race. Pastoralism is internationally significant for the 
communities it supports, the food stuff and environmental services it provides, the economic benefits it grants to some of the world's areas with the highest poverty rates and the long-lasting civilizations, it has helped survive to this day (Nori and Davies, 2007). Unluckily, threats relating to human populations, development, changes in land use and climate are challenging experts and managers to maintain and conserve these socially, culturally, economically, and ecologically precious assets around the world (Nori and Davies, 2007; Asrat and Simane, 2018).

Adaptation to climate change has been an important research topic, especially in agriculture, ever since climate change has been commonly recognized (Adger et al., 2003). There have been several studies investigating factors that affect adaptation to climate change in agriculture sector (Apata et al., 2009; Bryan et al., 2009; Below et al., 2012; Deressa et al., 2009, 2011; Hassan and Nhemachena, 2008; Seo and Mendelsohn, 2008a, b; Asrat and Simane, 2018; Hyland et al., 2015 and Lasco et al., 2015). Most of them have been conducted in developing economies where agriculture plays an essential role. In Southeast Asian countries, there have been significant variations in the intensity and frequency of extreme weather events associated with the changes in climate. The understanding of adaptation, however, is still limited as far as those countries are concerned (Francisco et al., 2008).

\section{Adaptation to climate change in the perspectives of rural livelihood}

Many research findings have highlighted the significance of policies related to climate change adaptation that can involve to deal the climate change issues (Adger et al., 2003; Hulme and Shepherd, 2003; IPCC, 2001, 2014). Adaptation is an approach that helps to manage ecological systems and socio-economic in reference to climate change consequence (Gallopin, 2006; Smit et al., 1999). Adaptation is generally considered as a capability of a society to form social capital in collective way (Adger, 2003). The capability and efficiency of climate change adaptation relies on the vulnerability of people and natural systems to climate adverse effects. The vulnerability "is the susceptibility to be damaged from pressures related with environmental and social change without having any capacity to cope with" (Adger, 2006). Ability to adapt climate change is context specific and varies among nations, communities, social groups and individuals over time (Smit and Wandel, 2006).

To minimize the vulnerability of an individual and a society to changes in climate has close connections with rural livelihood improvements, as poor livelihood is known as a condition and determinant of vulnerability (Tanner and Mitchell, 2008). According to Sen (1999), poverty is linked to inadequate outputs related to health, nutrition and literacy, as well with weaker social relations, insecurity, low self-worth and non-helping attitude. Sen (1999) comments that the basic ability of people improves their ability to question, challenge, propose and control new actions. Poverty has also linkage to social justice and is explained as "an incapability to contribute, due to limited resources" (Whelan, 2007). Thus, a multidimensional viewpoint of poverty highlights a broader picture of deficiency, social variables, relationships and structural aspects (Curwood and Eckerle, 2009; Frye, 2008).

\section{The climate change and livelihood perspectives in the study area}

In China, Grasslands occupy two thirds of the Tibetan Plateau's area (Cui and Graf, 2009), and climate change impacts on the plateau ecosystem have already been observed 
(Fu et al., 2012). The Tibetan Plateau is sensitive to global climate change because average air temperatures have increased at much higher rates $\left(0.16^{\circ} \mathrm{C} /\right.$ decade $)$ than Northern Hemisphere as a whole (Liu and Chen, 2000; Zheng et al., 2002). (IPCC) The Intergovernmental Panel on Climate Change projects that by 2050s, temperatures on plateau will increase more than $3{ }^{\circ} \mathrm{C}$ (IPCC, 2007), although precipitation changes on the plateau will likely be variable (Niu et al., 2004; Li and Kang, 2006; Xu et al., 2008).

Tibetan communities are dealing with the highly variable climate and winter snowstorms for many years. Traditionally, to live with the harsh climate, the Tibetan herders have developed a range of sophisticated strategies. These included migratory grazing over time and geographic space, flexibility in migration patterns and underlying social norms (e.g., reciprocity and trust), making use of diverse environment (e.g., seasonal pastures) and plant species, and the exchange of products from livestock and substance essential for daily living through local markets. Diversifying herd composition according to grassland vegetation is also employed to minimize the risk of livestock loss in harsh winters (Miller, 2002). These strategies helped them to lessen the damages during climate hazards and to have an efficient use of grassland resource base.

In the scenario of changes in climate, herder communities on the Tibetan Plateau would like to face more risks due to climate change. In order to improve Tibetan grassland social-ecological systems herders that are highly prone to climate changes should be capable to counter these changes. Governments are required to support and take advantage of adaptation strategies that are already being practice in a proven way further built up ability of herder communities to adapt. Thus, examination of historical adaptation mechanism based on livelihood and associated local institutional facilitators are important for this goal.

Strengthening of institution and changes in policies can support adaptation process by removing or introducing subsides and insurance systems, by supporting and inducing income diversification and early warning systems and other forecasting and crisisawareness systems. However, it is significant that pastoralist should help to devise these actions. Keeping in view climate change scenario, this study documented the socioeconomic profile of the pastoralists. The study also recorded the climate change perceptions and adaptation strategies by the pastorals. The data generated and recommendations made through this study would help policy makers, scientist and managers to improve grasslands and pastoral livelihood in Tibetan Plateau. The specific objectives of the present study include: i) to document community perception about climate change and the factors responsible develop this perceptions; ii) to document activities adopted by the pastoral communities for climate change adaptation and how they diversify their activities for sustainable livelihood; iii) to document the recommendations made by the pastoralists for improving capacity and efficiency for climate change adaptation.

\section{Materials and methods}

\section{Study area}

This research study was accomplished in Daiqian Village of Zhuaxixiulong Township of Tianzhu County of Tibetan Autonomous Region of Gansu Province, China and Dawu Village of MaqinGuoluo Prefecture Qinghai Tibetan plateau. The topography of Daiqian village is relatively diversified due to the topographic impact of Maya Snow Mountain to the south and Leigong Mountain to the north. Jinqiang River flows into the 
valley from west to east. Different landforms and communities of various plants and grasses are scattered along the river. The Dawu Village is located at Maqin County of Guoluo Prefecture of Qinghai Tibetan Plateau of Qinghai Province (Fig. 1). The salient features of the Daiqian Village and Dawu Village have been described in Table 1.

Table 1. Salient features of the selected villages

\begin{tabular}{l|l}
\hline \multirow{2}{*}{ Location } & $\begin{array}{l}\text { 1. Daiqian Village: Tianzhu County of Autonomous Region, Tibetan Plateau of } \\
\text { Gansu Province, China } \\
\text { 2. Dawu village: MaqinCounty of Guoluo Prefecture, Tibetan Autonomous } \\
\text { Region, Qinghai Province, China }\end{array}$ \\
\hline Geographical location & $\begin{array}{l}\text { 1. N } 37^{\circ} 14^{\prime}, \mathrm{E} 102^{\circ} 35^{\prime} \\
\text { 2. N } 34^{\circ} 28^{\prime} 11^{\prime \prime}, \mathrm{E} 100^{\circ} 12^{\prime} 39^{\prime \prime}\end{array}$ \\
\hline Elevation & $\begin{array}{l}1.3177 \mathrm{~m} \text { above sea level } \\
\text { 2. } 4200 \mathrm{~m} \text { above sea level }\end{array}$ \\
\hline Climate & $\begin{array}{l}1 . \text { Mean annual temperature, }-0.1^{\circ} \mathrm{C} ; \text { Mean annual precipitation, } 416 \mathrm{~mm} \\
\text { 2. Mean annual temperature, }-0.6^{\circ} \mathrm{C} ; \text { Mean annual precipitation, } 513 \mathrm{~mm}\end{array}$ \\
\hline Households & $\begin{array}{l}1.120 \\
\text { 2. } 180\end{array}$ \\
\hline Population & $\begin{array}{l}1.600 \\
\text { 2. } 1075\end{array}$ \\
\hline Vegetation & $\begin{array}{l}1 . \text { Alpine meadows } \\
\text { 2. Alpine meadows }\end{array}$ \\
\hline Major livestock types & $\begin{array}{l}\text { 1. White Yak, Tibetan sheep and others } \\
\text { 2. Yak, Tibetan sheep and others }\end{array}$ \\
\hline Livelihood & \multicolumn{1}{|c|}{ Mostly dependent on grasslands for grazing their livestock for livelihoods } \\
\hline
\end{tabular}

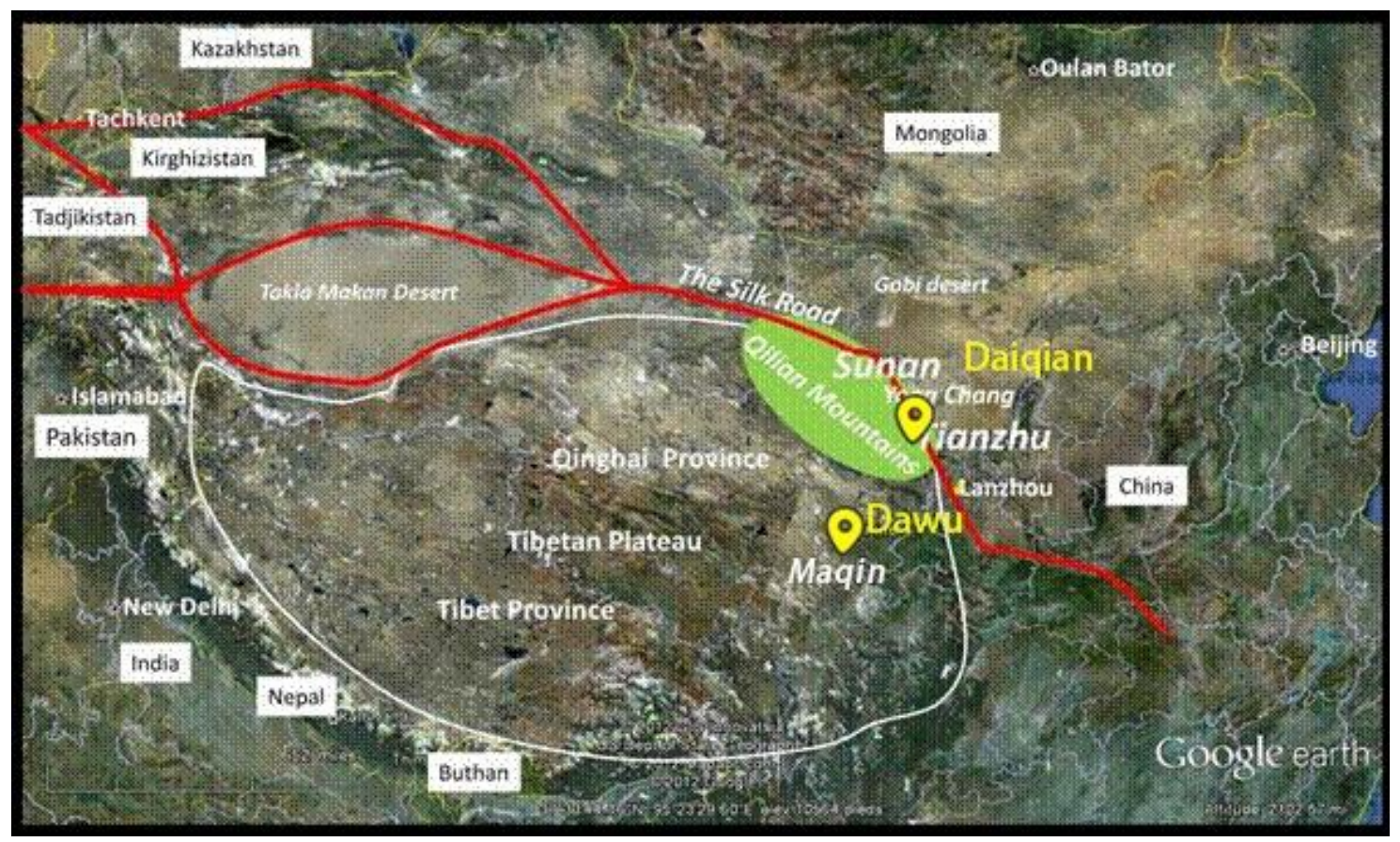

Figure 1. Study area (Daiqian \& Dawu). Red line is showing the Silk Road and green area is showing the Qilian Mountain. (Source: Google Earth $\left.{ }^{\circledR}\right)$ 


\section{Variation in climate parameters (temperature and precipitation) in study areas}

The climate of the study area is cold temperatures and most of precipitations occur in the form of snowfall due to its location at high altitude and dry temperature zone. The last two decades climate data (1991-2012) of the areas (Tianzhou county and Maqin county) is given in Figure 2. Along with the variation in annual precipitation of both counties (Tianzhou county and Maqin county) is given in Figure 3.

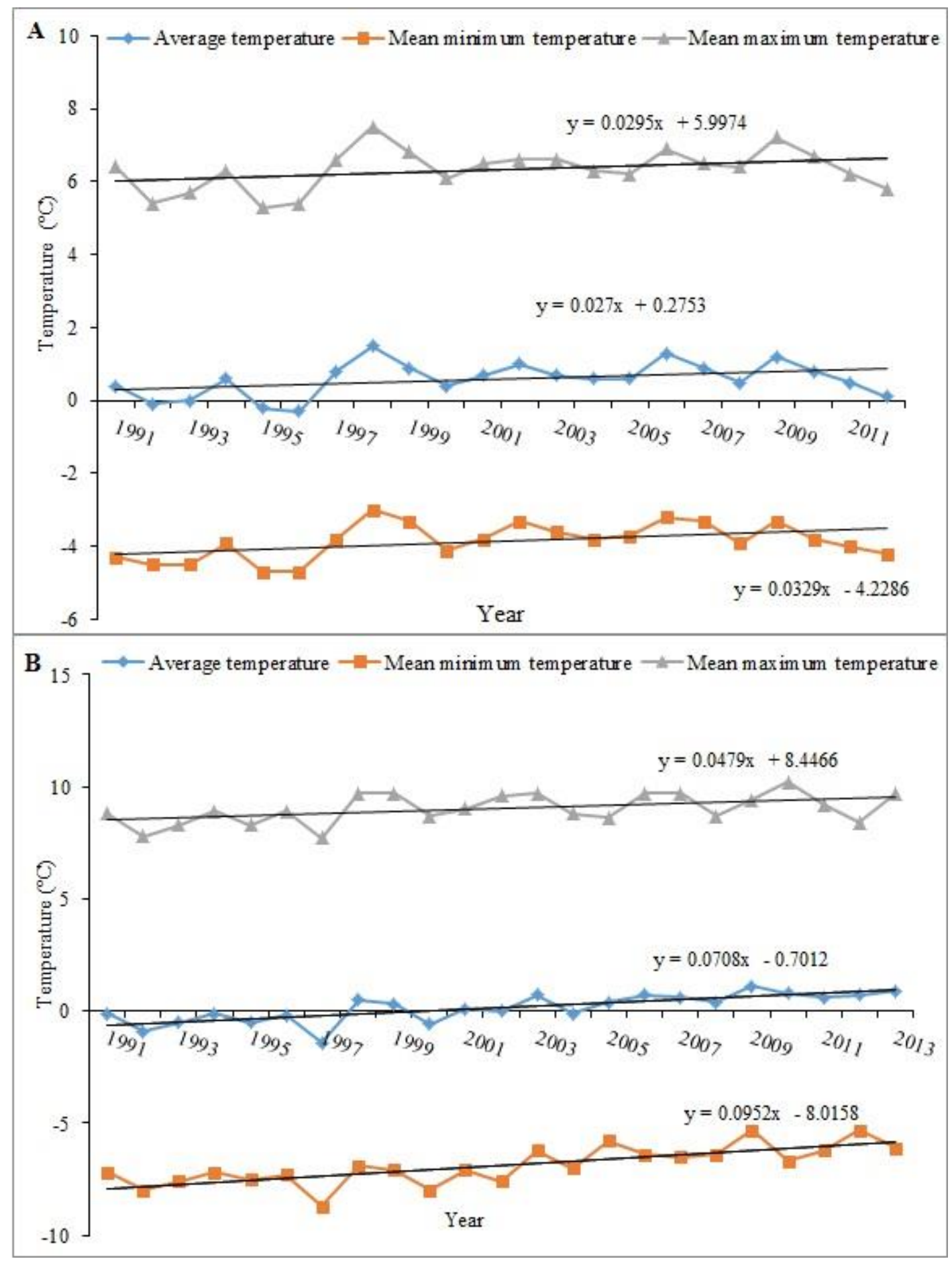

Figure 2. Variations in annual temperature data. A) Tianzhu County 1991-2011. B) Maqin County during 1991-2013 

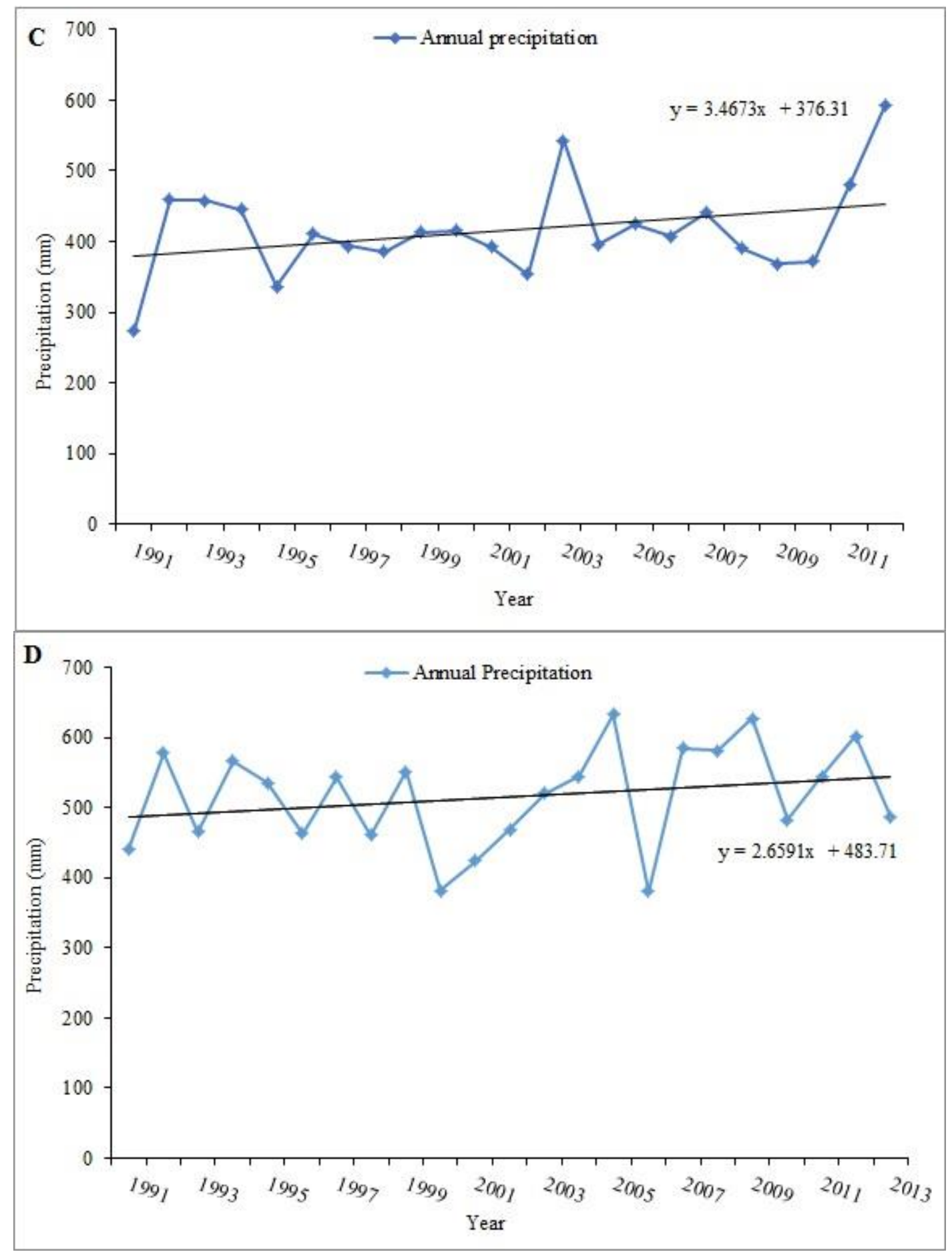

Figure 3. Variation in annual precipitation data. C) Tianzhu County 1991-2011. D) Maqin County during 1991-2013. (The climate data of Tianzhu County and Maqin County are from http://data.cma.cn/data/cdcdetail/datacode/surf_cli_chn_mul_yer.html, by permission)

\section{Increasing temperature}

Analyses of temperature variability over the last two decades in Tianzhou County have been given in (Fig. 2A). A gradual increase in average annual, mean maximum and mean minimum temperatures have been noticed in the study area. The trend line shows 
upward trend indicating a gradual increase in annual temperature from 1991-2013. For example, the mean maximum temperature ranges from $5.3^{\circ} \mathrm{C}$ in 1995 to $7.5^{\circ} \mathrm{C}$ in 1998 . Similarly, year 1998 and 1995 had the highest mean minimum temperature $-3.0^{\circ} \mathrm{C}$ and lowest mean minimum temperature $-4.7^{\circ} \mathrm{C}$, respectively. There is a sudden variation in temperature in Tianzhou County. The mean maximum temperature ranged from $7.2{ }^{\circ} \mathrm{C}$ in 2009 to $5.8^{\circ} \mathrm{C}$ in 2012 . In the same way year 2009 and 2012 had the highest mean minimum temperature $-3.3{ }^{\circ} \mathrm{C}$ and lowest mean minimum temperature $-4.2{ }^{\circ} \mathrm{C}$ respectively. In Maqin county (Fig. $2 B$ ) temperature is gradually increasing and is also highly variable. The mean maximum temperature in year 2010 and 2012 is $10.2^{\circ} \mathrm{C}$ and $8.4^{\circ} \mathrm{C}$ ) respectively. In this county in 1997 had the lowest mean minimum temperature $-8.3^{\circ} \mathrm{C}$ ) and 2009 and 2012 had the highest mean minimum temperature $-5.3{ }^{\circ} \mathrm{C}$ ).

\section{Erratic precipitation}

A noticeable variation in precipitation patterns over the last 22 years has occurred (Fig. 3C). In 1991 annual precipitation was recorded as the lowest $274 \mathrm{~mm}$ and in 2012 was recorded as the highest precipitation $592.8 \mathrm{~mm}$ during the last 22 years.

In Maqin County (Fig. 3D) the variation in annual precipitation is also noticeable. For example year 2005 had the highest annual precipitation $632 \mathrm{~mm}$ and year $2006 \mathrm{had}$ the lowest precipitation $380 \mathrm{~mm}$ during the last 22 years. The trend line shows an increasing trend both in temperature and precipitation in both of the study areas; however the deviation in the lower or higher case is much prominent that may be due to climate change effects. However the impact of these extreme variations may be much pronounced on grasslands and livestock health that actually helps pastoralists to perceive these variations.

\section{Pasture utilization and animal feeding calendar of a year}

The grazing period for animals is from mid-June to mid-August. The summer pastures are far from pastoralists' houses and all of the animals have free access to the pasture for grazing in summer. A generalized pasture utilization and animal feeding calendar of the year is given in Table 2 .

Table 2. Major features of livestock production system of study areas

\begin{tabular}{|c|c|c|c|c|c|c|c|c|c|c|c|c|}
\hline & January & February & March & April & May & June & July & August & September & October & November & December \\
\hline Animal's area & \multicolumn{4}{|c|}{ Winter pasture } & \multicolumn{3}{|c|}{ Summer pasture } & \multicolumn{2}{|c|}{ Autumn pasture } & \multicolumn{3}{|c|}{ Winter pasture } \\
\hline Grazing & \multicolumn{3}{|c|}{-} & + & ++ & \multicolumn{3}{|c|}{+++} & + & & - & \\
\hline $\begin{array}{l}\text { Supplementation } \\
\text { (forage) }\end{array}$ & \multicolumn{3}{|c|}{ Yes } & & & & & & & & Yes & \\
\hline $\begin{array}{c}\text { Supplementation } \\
\text { (concentrates) }\end{array}$ & \multicolumn{3}{|c|}{ Yes } & & & & & & & & & \\
\hline Milking & & & & & & \multicolumn{2}{|c|}{ Yes } & & & & & \\
\hline Calving period & & & & & Yes & & & & & & & \\
\hline Lambing period & & & Yes & & & & & & & & & \\
\hline Wool sales & & & & & & Yes & & & & & & \\
\hline $\begin{array}{l}\text { Animal selling } \\
\text { period }\end{array}$ & & & & & & & & & Yes & & & \\
\hline Planting period & & & & & Yes & & & & & & & \\
\hline Harvest & & & & & & & & & Yes & & & \\
\hline
\end{tabular}

-No grazing, +light grazing, ++moderate grazing, +++ heavy grazing 


\section{Data collection}

The data was collected through questionnaire and interviewing (see Appendix). 30 households were selected from Daiqian Village while 40 households were selected from Dawu village. The snowball sampling method was applied to approach the respondents. Snowball sampling approach is more appropriate to access the populations which are difficult to locate. Pastoralists often have scattered homes far from one another in the mountains and hilly areas with no proper access. So keeping in view we used snowball sampling method in this research. Interviewing helps scientists to look into the features of a society and know about a particular social fact by respondents own opinion (Dutcher et al., 2004). All interviews with villagers were taken with the help of Chinese interpreters, and all respondents showed their willingness to give interview. The data collected thus was tabulated in excel program.

\section{Data analysis}

For the purpose to describe and have a fair understanding about the collected data, data were analyzed using sociological statistic software known as Statistical Product and Service Solutions (SPSS 13.0 version, 2004) and Microsoft Excel. Based on the statistical results of the research conclusions were drawn. Statistical analysis base on best fit model, relying on the null hypothesis (H0) that an effect does not exist whereas the alternative hypothesis (H1) is contrary to that (Field, 2009). The acceptance or declining of the null hypothesis base on the probability value (p-value), that is to be related to the confidence interval around the average value of a tested response variable. A 95\% confidence level was considered in this study and then, if the p-value is below or equal to 0.05, the null hypothesis is declined. Descriptive statistics, binomial and chisquare tests were also applied in this data analysis.

\section{Binomial test}

To examine whether respondents perceive (category I) or not perceiving (category II) about the statement of climate change perception, we carried out a binomial analysis. This analysis was also used for frequencies for category I and II of the variables "perception", "impacts" as well "adaptations" that have been explained in Table 3. Binomial test also examines frequencies of every class of "Yes" and "No". In our research we examined either the frequencies of category I differs from the category II. In this case null hypothesis (H0) was created like "the frequency of category I (Yes) is higher than the frequency of category II (No)".

\section{Chi-square test}

In order to better understand the relationship between two categorical variables Pearson Chi-square test was applied. The analysis gives a judgment between the observed frequency level in a category and the expected frequencies by testing perfect random possibility (Field, 2009). A null hypothesis was created "there is no relationship between the two variables" and a substitute hypothesis (H1) describes "there is a relationship between the two variables". There is a key supposition in this analysis that expected frequencies must be more than 5 . If every variable has only two categories, we should use Fisher's exact test. The Pearson chi-square tests results are not consistent every time, and can be considered investigative only. 
Table 3. Description of the variables changed to a categorical scale

\begin{tabular}{|c|c|c|c|}
\hline Variables & Description & Category I & Category II \\
\hline $\begin{array}{l}\text { Factors for } \\
\text { developing } \\
\text { climate change } \\
\text { perception }\end{array}$ & $\begin{array}{l}\text { The following helped to develop climate change } \\
\text { perceptions } \\
\text { Personal observations } \\
\text { - } \\
\text { Government department } \\
\text { TV programs } \\
\text { Weather forecast }\end{array}$ & Yes/agree & No/disagree \\
\hline $\begin{array}{l}\text { Awareness of } \\
\text { weather }\end{array}$ & $\begin{array}{l}\text { Farmers awareness about the changes in climatic } \\
\text { conditions } \\
\text { - Temperature is rising } \\
\text { - Rainfall is decreasing }\end{array}$ & Yes & No \\
\hline $\begin{array}{l}\text { Impacts on } \\
\text { resources }\end{array}$ & $\begin{array}{l}\text { Are there any adverse effects of climate change on } \\
\text { grasslands and livestock? } \\
\text { - Grassland degradation } \\
\text { - Negative impacts on livestock health } \\
\text { - Deaths in livestock }\end{array}$ & Yes & No \\
\hline Adaptation & \begin{tabular}{|l} 
Are they adapting the climate changes? \\
- Water harvesting \\
- Forage cultivation \\
- Good quality seed \\
- $\quad$ Concing \\
- \\
\end{tabular} & Yes & No \\
\hline
\end{tabular}

\section{Results}

Displayed results contribute a better insight of pastoralist's perceptions about climate change and their adaptation for these changes. It will help the governments to find the best possible incentives, measures and interventions to improve the adaptation practices and protect the natural, environmental and cultural resource on a sustainable base that has a unique global importance. Firstly, the participant's general demographic characteristics are described; containing gender, age, education, household including their socioeconomic profile about incomes and expenditures. Secondly, perception of the pastoralists including contributing factors leading to develop climate awareness in pastoralist has been described. Thirdly, measures taken by the pastoralists to adopt issues associated to climate change and diversification of livelihood have been discussed. Lastly, the recommendations made by the pastoralists to enhance climate change perception and adoption in Tibetan Plateau have been explained.

\section{Demographic profile of pastoral community}

Table 4 shows the demographic profile of the respondent pastoral communities of the Daiqian Village and Dawu Village. The respondents from Daiqian village consists of $66.33 \%$ male and $36.37 \%$ female while in Dawu village most of the respondent were men $92 \%$ and only $8 \%$ were the female respondents. The age of the respondents ranges from 30 to 70 years. Majority of the respondent (40\%) in Daiqian village belonged to 40-50 years age group as compared the $50 \%$ of the Dawu village respondents belonged to age group of 30-40 years. In Daiqian village majority of the respondents (41.9\%) got their education up to primary level while in Dawu village majority of the respondent 
were illiterate as the $85 \%$ of the respondent had no education. The household size of the respondents was divided into less than five members and greater than five family members. In Daiqian village majority of the respondent have family size of the $\leq 5$ that counted about $73 \%$ while in Dawu about $50 \%$ of the respondents were having family member $\leq 5$.

Table 4. Demographic profile of pastoral communities of selected villages

\begin{tabular}{c|c|c|c}
\hline Variable & Category & Daiqian village & Dawu village \\
\hline \multirow{3}{*}{ Gender } & Male & $19(66.33 \%)$ & $37(92 \%)$ \\
& Female & $11(36.67 \%)$ & $3(7.5 \%)$ \\
& Total & $30(100 \%)$ & $40(100 \%)$ \\
\hline \multirow{3}{*}{ Age (years) } & $30-40$ & $8(26.66 \%)$ & $20(50 \%)$ \\
& $41-50$ & $12(40.0 \%)$ & $11(27.5 \%)$ \\
& $51-60$ & $8(26.67 \%)$ & $2(05.0 \%)$ \\
& $61-70$ & $2(6.66 \%)$ & $7(17.5 \%)$ \\
\hline \multirow{2}{*}{ Education } & Illiterate & $12(40 \%)$ & $34(85 \%)$ \\
& Primary & $13(41.9 \%)$ & $6(15 \%)$ \\
& Elementary & $5(16.1 \%)$ & 0 \\
\hline \multirow{2}{*}{ Household size } & $\leq 5$ & $22(73.33 \%)$ & $21(52.5 \%)$ \\
& $>5$ & $8(25.8 \%)$ & $19(47.7 \%)$ \\
\hline
\end{tabular}

\section{Rural household resources and socio-economic characteristics}

Rural household resources and socio-economic profile of the respondent communities of Daiqian village and Dawu village have been recorded in Table 5. Both of the villages have minimum household size of family members of 03 while on the other hand Dawu village have maximum number of family members up to 09 as compared to 07 members of Daiqian village. The mean pasture land holding size of Daiqian and Dawu is (13 ha) and (33 ha) respectively. The maximum land holding size for pasture is (38 ha) while in Dawu it reached to (133 ha). The mean mobility of the herder in Daiqian and Dawu village was recorded as $3 \mathrm{~km}$. Mean annual income were found in Daiqian (7886 \$), that were more in Dawu (8422 \$). Similar trend was observed in mean annual expenditures in both villages. Mean livestock number was more in Daiqian as compared to Dawu village.

Table 5. Rural household resources and socio-economic characteristics of study areas

\begin{tabular}{c|c|c|c|c|c|c|c|c}
\hline & \multicolumn{4}{|c|}{ Daiqian } & \multicolumn{4}{c}{ Dawu } \\
\cline { 2 - 9 } & N & Min & Max & Mean & N & Min & Max & Mean \\
\hline Household size & 30 & 3 & 7 & 4.47 & 40 & 3 & 9 & 5.38 \\
Land holding (ha) pasture area & 30 & 04 & 38 & 13 & 40 & 5.3 & 133 & 33 \\
Mobility & $>5 \mathrm{~km}$ & 1 & 5 & 3 & $>5 \mathrm{~km}$ & 1 & 5 & 3 \\
Annual income (\$) & 30 & 2830 & 15094 & 7886 & 40 & 1146 & 35631 & 8422 \\
Annual expenditures (\$) & 30 & 1190 & 11901 & 6001 & 40 & 2496 & 17968 & 6874 \\
Livestock & 30 & 50 & 350 & 152.47 & 40 & 15 & 458 & 109.20 \\
\hline
\end{tabular}




\section{Economic profile of the selected respondent communities}

Figure 4 explained the economic profile including the income sources and types of various expenditures incurred of the respondent communities of Daiqian and Dawu villages during the year. Major income sources included livestock sale, wool sale, caterpillar fungus sale, subsides and other including labor, sale of milk , dung etc while the major expenditures include buying livestock, daily living (food and other things), medical, livestock feed, vaccination and others. Livestock sale, subsidies were among the major income sources for both of the communities while living and animal feed were among the major expenditures of the respondent communities.

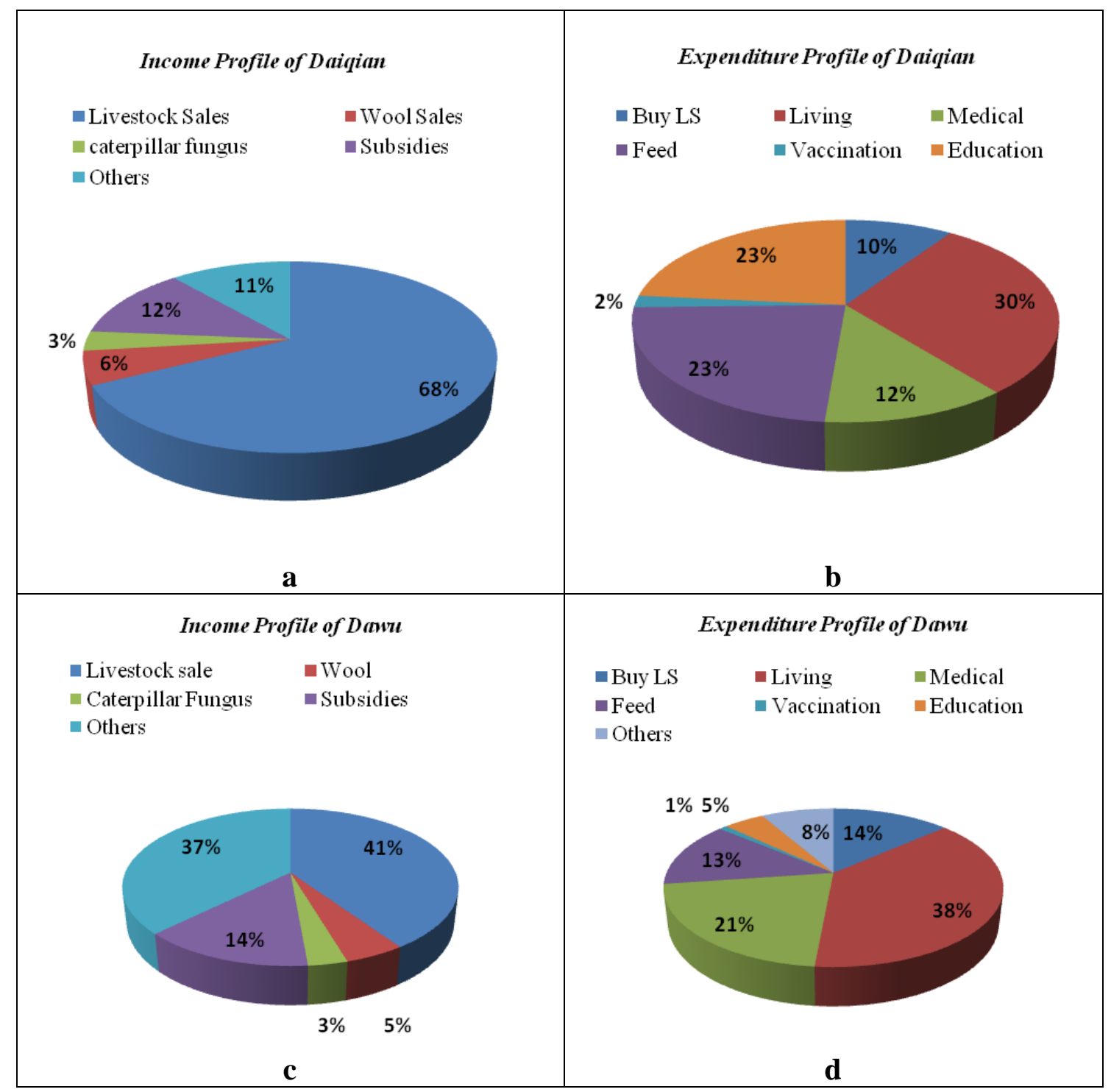

Figure 4. Income and expenditure profile of the pastoral community

\section{Pastoralist's perceptions about climate change}

The data presented in Figure 5 has shown the responses of the pastoral communities about climate change perception. Responding to the question whether they know about 
climate change or not. $83.3 \%$ of the respondents belonging to Daiqian village were aware of the climate change issues while about $16.7 \%$ of the respondents were not aware of the climate change phenomenon at all. As compared to Daiqian, the pastoral community of the Dawu was less aware of the climate change. However majority of the respondents of Dawu village $75 \%$ had the knowledge about climate change while $25 \%$ did not have awareness about climate change (Table 6).

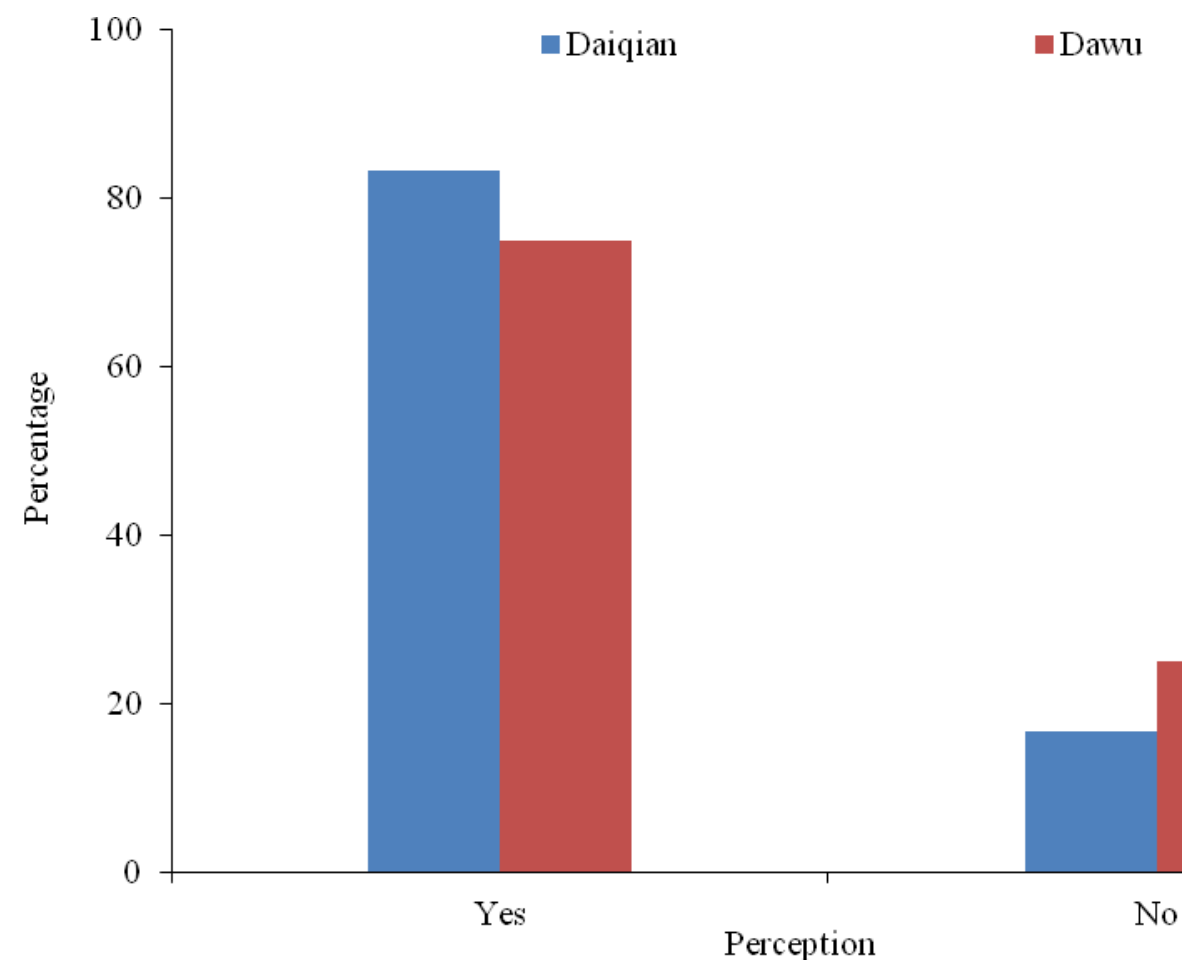

Figure 5. Pastoralist's perceptions about climate change in selected villages

Table 6. Climate change perception and factors for perception development

\begin{tabular}{c|c|c|c}
\hline Variable & Statement & P value Daiqian & P value Dawu \\
\hline Knowledge about climate change & Know about climate change & .000 & .001 \\
\hline \multirow{2}{*}{$\begin{array}{c}\text { Factors for developing climate } \\
\text { change perception }\end{array}$} & Personal observations & .043 & .006 \\
& Government department & .000 & .000 \\
& TV programs & 1.000 & .006 \\
& Weather forecast & .000 & .002 \\
\hline
\end{tabular}

Majority of the respondents $72.5 \%$ in Dawu village were having a personal experience to judge the climate change issue while only $30 \%$ in Daiqian village have examined the climate change through personal observations (Table 7). The other factor contributing in the development of climate change awareness among pastoralist included Government Departments, weather forecast program, TV programs and multiple sources. Weather forecast program and TV program jointly contributed in developing perception among $13(43 \%)$ and $16(40 \%)$ of the respondents in Daiqian and Dawu respectively. 
Table 7. Different tools of climate change perceptions among respondents

\begin{tabular}{c|c|c}
\hline \multirow{2}{*}{ Sources of climate change perception } & Daiqian & Dawu \\
\cline { 2 - 3 } & Frequency/percent & Frequency/percent \\
\hline Personal observation/experience & $9(30.0 \%)$ & $29(72.5 \%)$ \\
From government department & $2(6.7 \%)$ & $3(7.5 \%)$ \\
Weather forecast & $5(16.7 \%)$ & $10(25.0 \%)$ \\
TV program & $8(26.7 \%)$ & $6(15.0 \%)$ \\
Multiple sources & $15(50.0 \%)$ & $11(27.5 \%)$ \\
\hline
\end{tabular}

\section{Perceived impacts of climate change}

After recording the pastoralists knowledge about climate change and tools helping to develop awareness about climate change, next to that pastoralist were asked about the perceived impacts of climate change. Figure 6 shows, in Daiqian village, most of the participants $(18 \%)$ perceived changes in climate in the form of rise in annual temperatures in the area $(p=.043)$ while $29 \%$ of the respondents perceived changes in climate in the form of low rainfall and rainfall variations $(p=.000)$. The other perceived negative impacts of climate change in Daiqian were low production of the grasslands $(12.5 \%)$, poor animal health $(15 \%)$ and death of animals $(12.5 \%)(=.000)$. On the other side, 17.5 and $15 \%(\mathrm{p}=.000)$ of the respondent in Dawu village increase in temperature and lower rainfall distribution respectively (Fig. 6).

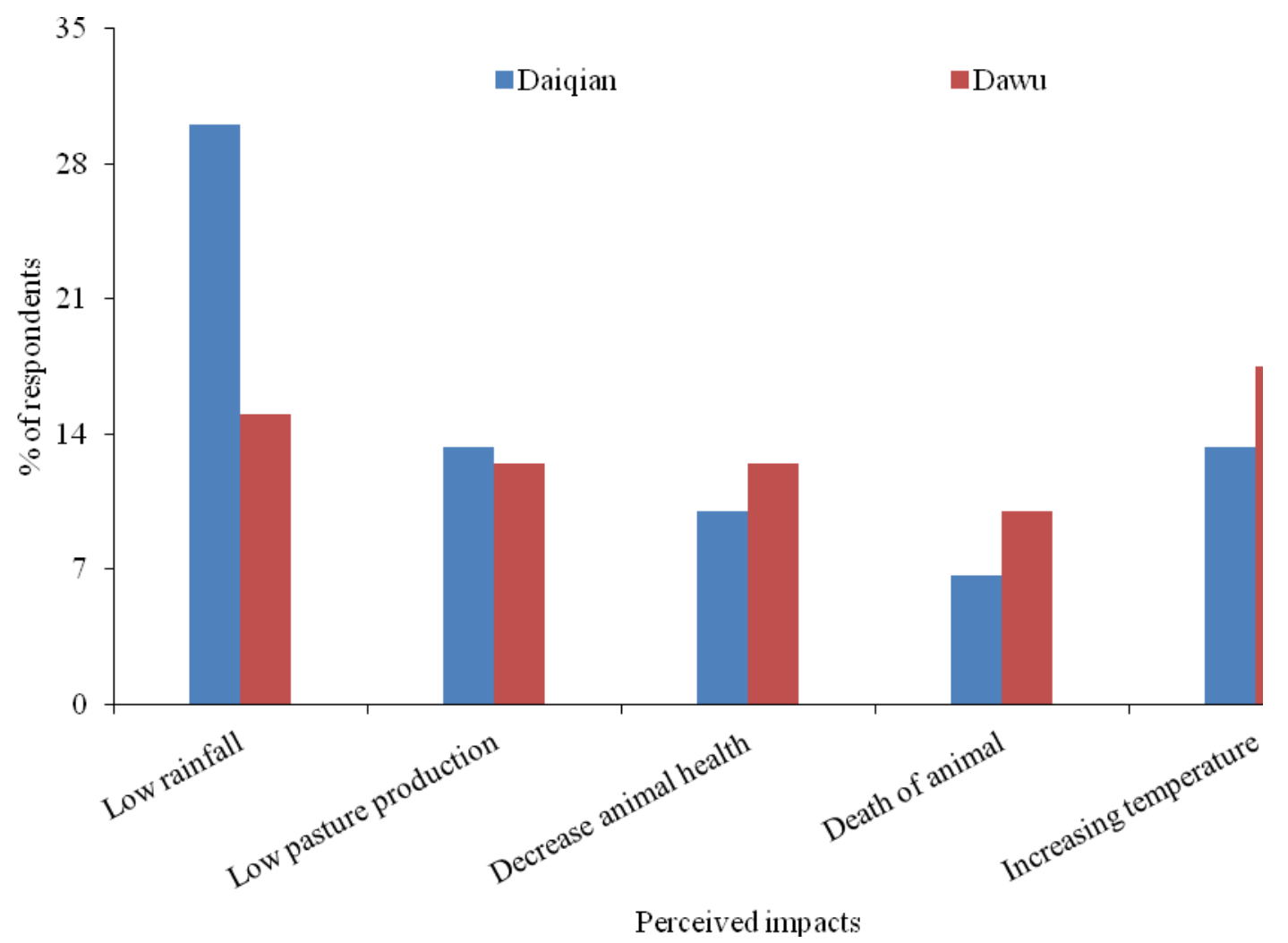

Figure 6. Perceived impacts of climate change by pastoral communities 


\section{Climate change adaptations}

The data about adaptation measures being practiced by the pastoralists have been presented in Figure 7. In Daiqian village having mixed livestock was one of practice that being adopted by majority of the respondents of $86.7 \%(p=.000)$, the having mixed livestock not only helps to utilize the available grassland resources but also can be voided loss in case of any epidemic to one type of livestock. In addition smaller animal can be sold as and when needed due to shorter age of maturity and high prices to sustain the livelihood. In Dawu village about $57.5 \%$ were having the mixed livestock. Controlled grazing was being adapted by the respondents $(60 \%)$ of both of villages equally to minimize the climate impacts on their daily life management scenario, Good quality seed for forage cultivation and fencing to pasture area were also recorded as the strategies to reduce climate change impacts on livelihood of the pastoralists.

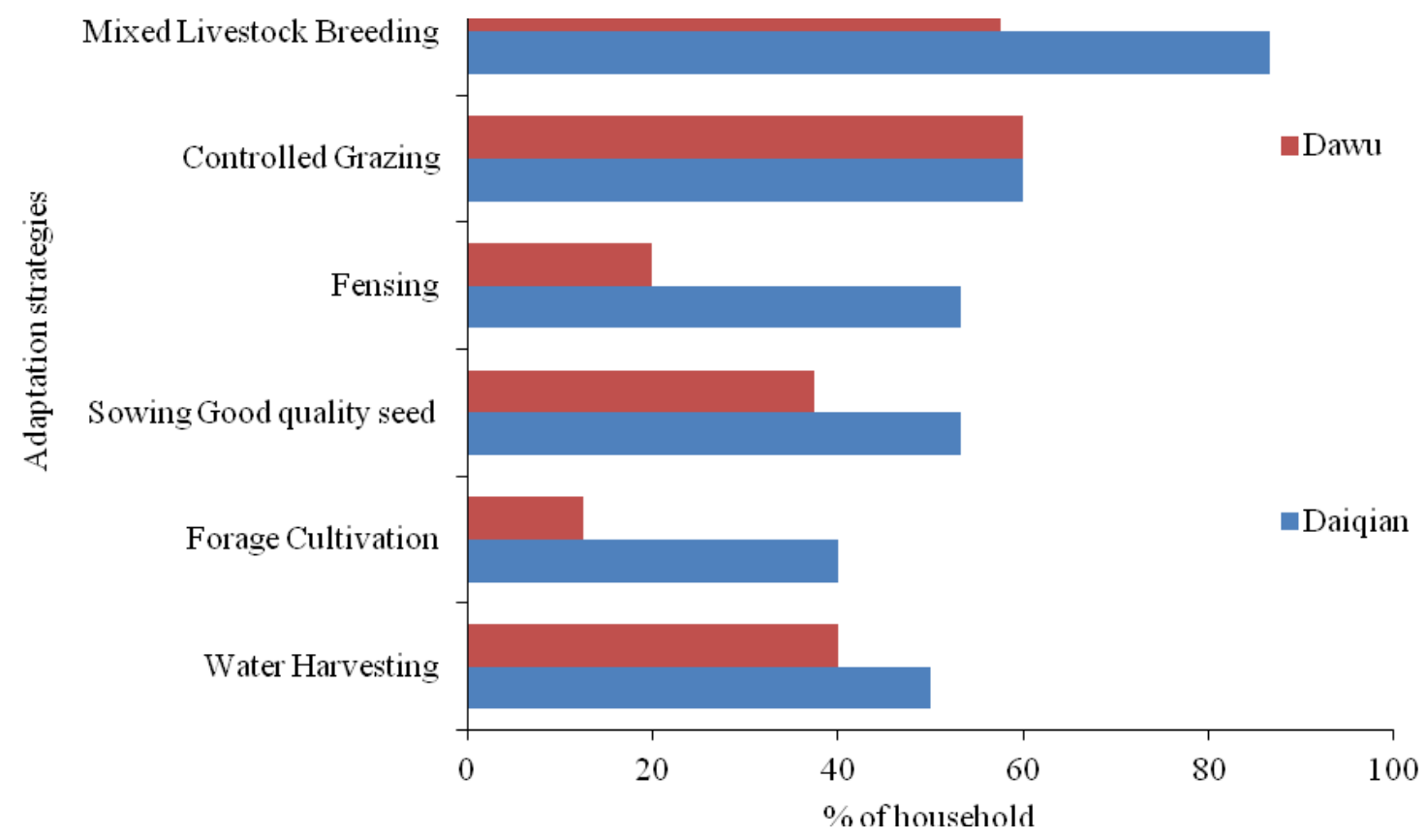

Figure 7. Climate change adaptation measures by selected communities

\section{Relationship between demographic factors and climate change perception and adaptation}

The demographic factor may have had an effect on the climate change perception, impacts and adaptation. It was tried to expose such relationship through chi-square tests. If these relationships are known, it will be easier to develop sufficient and area specific governmental intervention. Table 8 describes the results about the relationship is significant or not. The data shows that only the age is one of the significant factors in Daiqian village that may influence their given answers significantly for developing the perception among the pastoralists. Similarly education is Daiqian village could possibly be helpful influencing the knowledge of the respondents about climate perceptions. Similarly household could positively be able to contribute in developing the perception of climate change knowledge in respondents. 
Table 8. Relationship between demographic factors and climate change perception and adaptation

\begin{tabular}{c|c|c|c|c|c|c|c}
\hline Daiqian & Knowledge & Impact & Adaptation & Dawu & Knowledge & Impact & Adaptation \\
\hline Gender & .381 & .310 & .470 & Gender & .411 & .704 & .348 \\
Age & $.036^{*}$ & .748 & .375 & Age & .471 & .641 & .441 \\
Education & $.063^{*}$ & .977 & .557 & Education & .153 & .351 & .456 \\
House hold size & .757 & .275 & .927 & House hold size & $.058^{*}$ & .331 & .468 \\
\hline
\end{tabular}

*Significant relationship $\mathrm{P}<0.1$

\section{Livelihood diversification}

Livelihood diversification is considered as one of the effective tools that not only helps pastoralists to manage climate change effects but also supports sustainable livelihood by enhancing income levels of the pastoralists. While responding about livelihood diversification mixed livestock was considered as one of the major activity in both of the villages because it is not only utilizes the pastures in a better way but sheep and goats can be sold as and when needed to meet the urgent needs (Fig. 8). However in Daiqian village about $86.7 \%$ of the pastoralists were having mixed livestock to sustain their lives and meet their daily needs where in Dawu only $57.5 \%$ were having the mixed livestock. Almost all of the pastoralists were selling wools of their animal to earn some money. In addition collection and selling of caterpillar fungus, labors were also recorded as means to diversify pastoral income in Daiqian and Dawu villages.

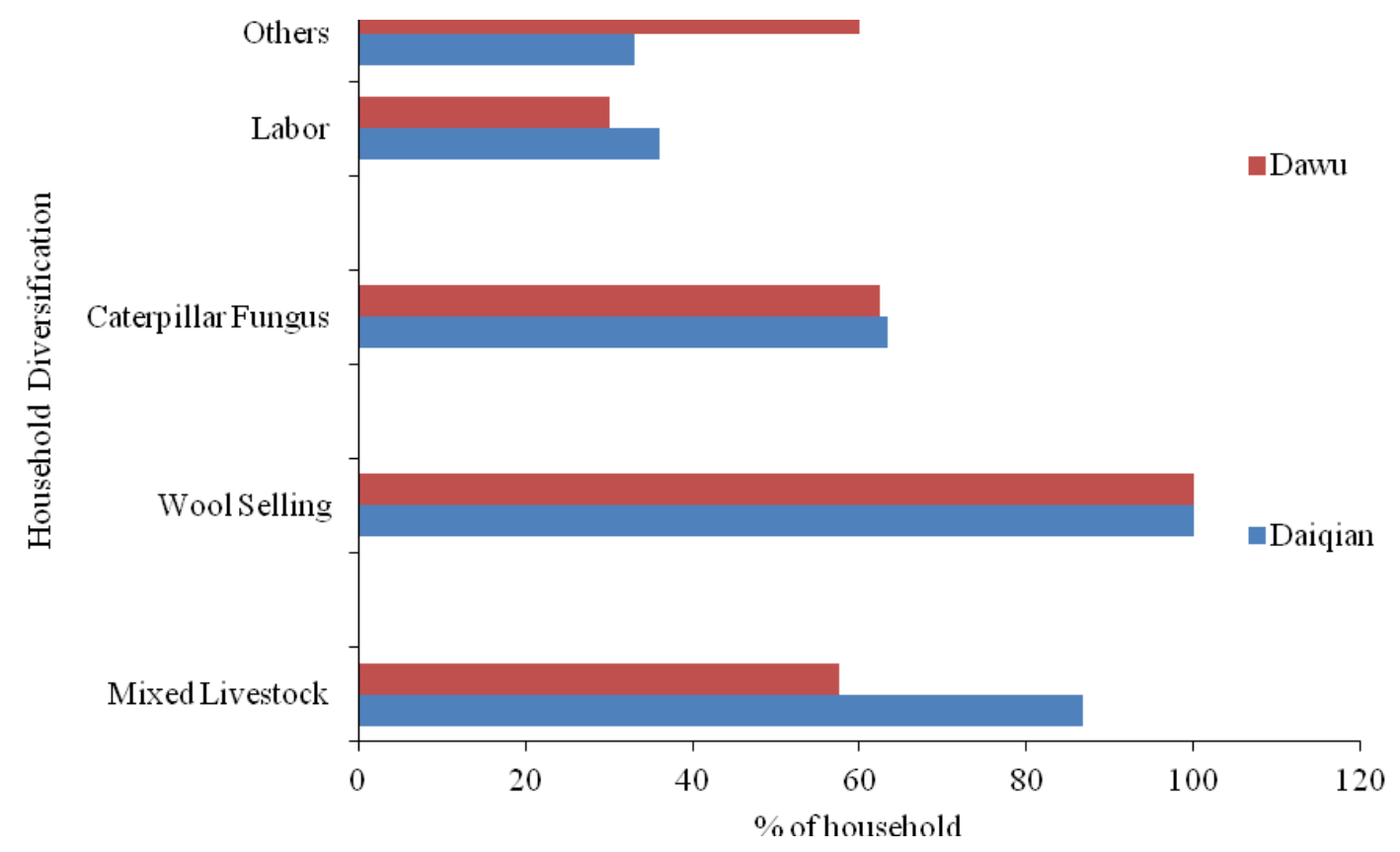

Figure 8. Livelihood diversification measures by pastorals in Daiqian and Dawu villages

\section{Institutional set up and government policies}

The pastoralists were asked whether they know about the institutional set up and government policies about different sectors in their villages. Responding to the 
questions most of pastoralists in villages were aware about pasture management institution and policies Table 9. In Daiqian village 56.7\% and Dawu village 60\% of the villages were aware about the pasture management and related policies. Following to the pasture management, people were aware about the credit organizations in both villages as in Daiqian $46 \%$ and Dawu 15\%. People in both of the villages were also having more or less information about NGOs, Water management and Agriculture management both villages.

Table 9. Institutional set up and government policies

\begin{tabular}{c|c|c|c|c|c|c}
\hline \multirow{2}{*}{ Govt. Policies } & \multicolumn{3}{|c|}{ Daiqian } & \multicolumn{3}{c}{ Dawu } \\
\cline { 2 - 7 } & Yes & No & Don't know & Yes & No & Don't know \\
\hline Water management & $26.7 \%$ & $36.7 \%$ & $36.7 \%$ & $55 \%$ & $37.5 \%$ & $7.5 \%$ \\
Pasture management & $56.7 \%$ & $6.7 \%$ & $36.7 \%$ & $60 \%$ & $32.5 \%$ & $7.5 \%$ \\
Agriculture management & $10.0 \%$ & $53.3 \%$ & $36.7 \%$ & $7.5 \%$ & $85.0 \%$ & $7.5 \%$ \\
Credit organization & $46.7 \%$ & $16.7 \%$ & $36.7 \%$ & $15 \%$ & $77.5 \%$ & $7.5 \%$ \\
Disaster relief and rescue & $40.0 \%$ & $36.7 \%$ & $23.3 \%$ & $77.5 \%$ & $15.0 \%$ & $7.5 \%$ \\
NGO's & $30.0 \%$ & $40.0 \%$ & $30.0 \%$ & $22.5 \%$ & $67.5 \%$ & $10.0 \%$ \\
\hline
\end{tabular}

\section{Key recommendations by pastoralists to mitigate future effects}

Pastoralists are the key custodians of the grasslands of the Tibetan Plateau. They can play a significant role in the conservation of this resource base if their opinion is given due consideration and noticed their needs in this regards. Keeping in view it was sought to put a question about their recommendation to not only conserve this resource but this unique diminishing social and cultural heritage of pastoralism (Table 10). The majority of the Daiqian respondents $(26 \%)$ recommended that grassland degradation should be controlled. Secondly they recommended (20\%) that their capacity should be built through training about pasture and climate change management as well as similar number of respondents recommended watering points for live stocks. In addition about $16.7 \%$ of the respondents suggested developing forage bases and introduction seed of drought and cold tolerant good forage varieties. In the case of Dawu village capacity building for pasture and climate change, establishment of watering points for grazing livestock in the pasture area, development of forage base with introduction of good variety seed were recorded (Table 10).

Table 10. Key recommendations by pastoralists to mitigate future effects

\begin{tabular}{c|c|c}
\hline Recommendations by pastoralists & Daiqian (\%) & Dawu (\%) \\
\hline Awaining of pasture knowledge and climate change scientific management & 20.0 & 17.5 \\
The establishment of livestock water points & 13.3 & 10.0 \\
Strengthening governance about the protection of natural grassland & 20 & 17.5 \\
Increase grassland degradation control & 26.7 & 10.0 \\
Development of forage base and cultivate new varieties of drought resistant & 16.7 & 10.0 \\
Infrastructure for drinking water & 6.7 & 5.0 \\
Strengthen meteorological disaster forecast & 10.0 & 17.5 \\
\hline
\end{tabular}




\section{Discussion}

\section{Farmer's perceptions about climate change}

This study noticed some important findings about the perception. The study found that the participated pastoralists had knowledge about climate changes and its impact on their lives and associated resources. The findings are in line with the results of Thomas (2008) who found that farmers could recognize changes in climate and increased variability in natural climatic conditions due to climate change. In some sense, communication on climate change has been enormously successful. Across nations, almost everyone in study area has heard the issue and many can identify at least some important climate change impacts (Leiserowitz, 2007). In this study, communication way like electronic media, weather forecast information has been noticed as the tool to develop perception of the respondent about climate change. It is therefore, suggested that government institutions and policy makers could use media as a tool for developing climate change perception among masses. The awareness about climate change is related to age thus older pastoralists have better understanding about climate change that may be based on their experience to observe these changes. Pastoralists in Tibetan Plateau indicate a declined precipitation and increased temperatures with a short rainy spell. The comparable findings were reported by several other researchers as (Lema and Majule, 2009; Wongtschowskiet al., 2009; Zampaligréet al., 2013). Pastoral perceptions have been verified by the long term climate data examination that highlighted a decreasing tendency in rainfall pattern with a mild to highly worst drought frequency, and increase in temperature. The findings of (IPCC, 2007) observed a universal shortage in rainfall with increased temperatures along with a hint that there will be higher rainfall occurrence in some areas, while many other areas will receive insufficient rainfall. The Tibetan plateau may fall in the second scenario having low rainfall. However, if local people's native knowledge about prediction of weather changes has been interrupted, this may lead to inefficiency of local mitigation and adaptation strategies (Nyonget al., 2007). Agro-pastoralists understand that change and inconsistency in climatic conditions effects grasslands, water resources, animal vigor and productivity. Actually, the production of agriculture, grasslands and water resource are greatly associated with climatic parameters such as precipitation and temperature. Decline in rainfall causes a reduced pasture production (Lema and Majule, 2009; IUCN, 2010). Increase in temperatures accelerates evapotranspiration rate by plants which leads to condition of drought (IPCC, 2007). Pastoralists' perceptions about the impacts of global change on the pastures have also been noticed by Wongtschowskiet al. (2009) and Zampaligreet al. (2013). They concluded that forage availability, the soil quality and the pastures specie composition (e.g. biodiversity) is affecting by climate change.

\section{Adaptation strategies and livelihood diversification}

Transformation in livestock possessions and livestock management systems, are fundamental for adaptation of long term global changes (Deressa et al., 2009). It was noticed that mixed live breed holdings by the pastoralists is one of the major adaptation measures in the area. This can help to not only face issues related to climate aspects but also sustain livelihood prospects. The mix livestock breed helps not only to use different types of forage and livelihood sustainability, as sheep and goats are sold out as and when needed as compared to yak that needs long time for getting more money. For efficient and better adaptation of the impacts of climate change and variability 
pastoralists diversify their livestock species, cultivate supplementary forage and practice other measures (Fig. 9).
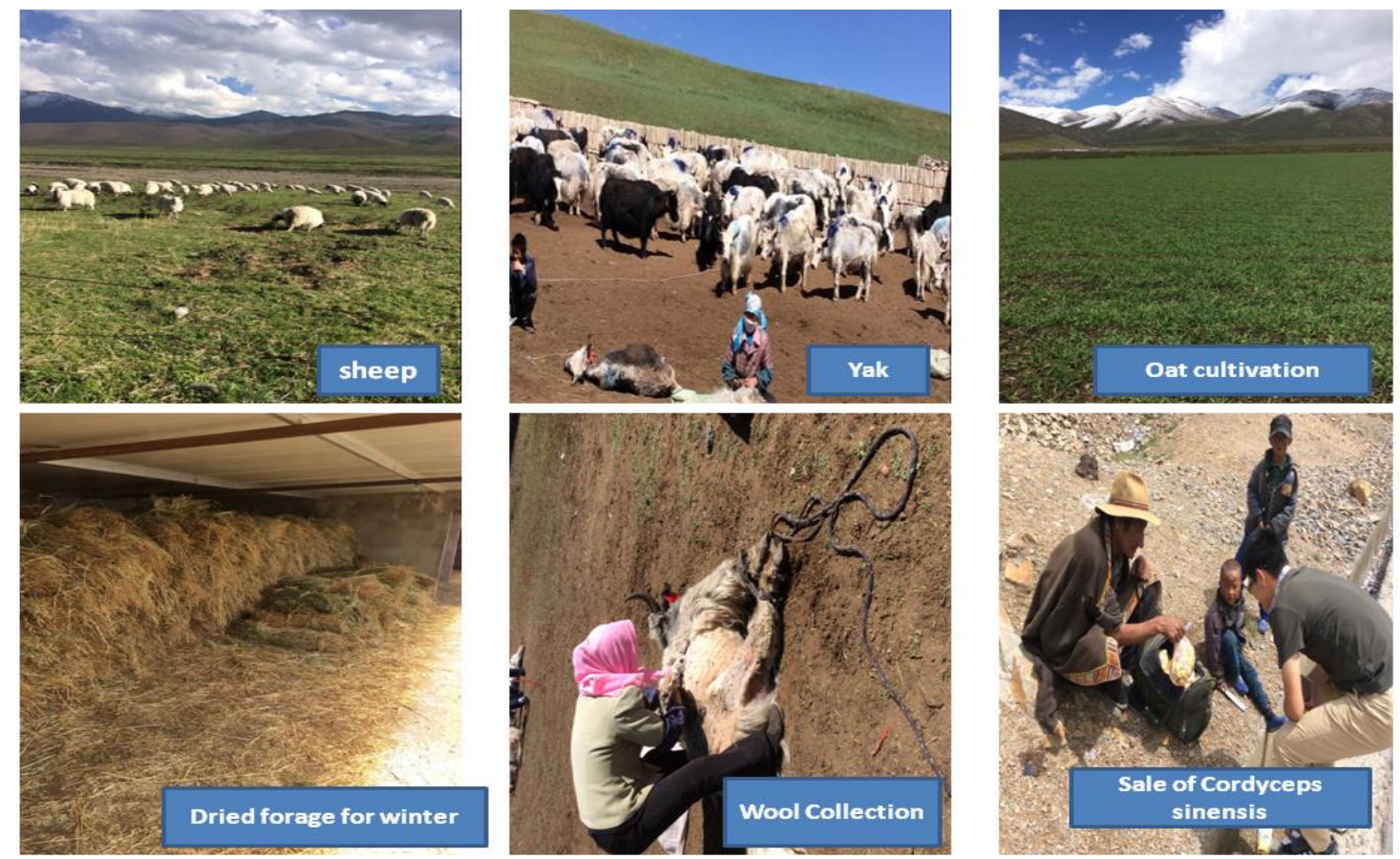

Figure 9. Pictorial representation of some adaptation and livelihood practices by pastoralists of the selected villages

The sheep and goat have a significant role in pastoral livestock production system by allowing the pastoralists to fulfill their instant socioeconomically requirements (Malonine, 2006). Diversification by means of forage production not only produces cereals for their own food but also feed for their livestock from crop straw residues. In addition, to perform diversification crop farmers also practice shifting cultivation, enlarge their cropland, and grow superior plant breeds. However, the increased frequency and harsh intensity of climate events (floods, droughts) and the rainfall variations are posing bigger threats to the pastoralists' adaptive capacity (Kandjiet al., 2006). Farmers become more vulnerable to climate changes if they don't have very good ability to adapt climate change effects for their resilience. The pastoralists were of the view that training should be imparted to them for building their capacities to perceive and mitigate climate change issues.

\section{Conclusions}

Pastoral perception of climate change and analysis of climate data both showed a decrease in rainfall and an increase in temperatures with a reduction of rainy season in study area. Personal experience and electronic media are main factors for developing climate awareness among local pastoralist, so these should be taken into consideration while launching campaigns and initiatives about climate awareness and adaptation in the plateau. Climate change and deviation have affected the accessibility of natural resources such as pasture, water, livestock production, and livestock health 
deterioration. Due to strong negative effects on people's welfare and safety, climate change is a huge risk to pastoral safety. To adapt these impacts of climate change and variability pastoralists shifted from monoculture (yak) of livestock to mixed species (yak + sheep + goats) and diversification of income sources. Adaptation to climate change has to be included in disaster risk reduction policies and should be regularized into land plans policies at national, local and regional levels.

Keeping in view above concluding paragraph following recommendation are made:

- Migration, ethnicity and religious believes could be important factors to develop climate change adaptation among pastorals societies, it is therefore recommended that future studies may be conducted while addressing these parameters.

- Electronic media and weather forecast programs have been indicated by the pastoralist as an effective tool for developing awareness among the pastoralists. Government and policy institutions can strengthen these sources and develop an effective mechanism for their efficient use for developing knowledge about climate change in the area.

- Personal experience and education have a strong relationship with knowledge about climate change, so Government should consider these factors while developing mechanisms

- The development of cottage industry associated to livestock products can help pastorals to improve their livelihood. There are opportunities for organic meet production and its processing, commercial production of caterpillar fungus and cottage industry related to livestock products like wool products and cheese production. All these opportunities can help to improve their livelihood and also can enhance their adaptation to the adverse effects of climate change.

- In order to improve an efficient adaptation to climate change on the bases of long term, planned adaptation is necessary. Therefore, government should offer financial in it will reduce the financial risk for the farmer. But it should be given as a reward on the bases of the pastoralists' performance for adopting good practices for climate and resource conservation.

- Pastoralists are the key custodians of the grasslands of Tibetan Plateau so they should be given a central place while developing policies and initiatives for climate change mitigations and resource restoration in the area.

Acknowledgements. The present study was financed by China Scholarship Council (CSC), China award No. 2014GXZB87, for Master Studies in Environmental Sociology at Lanzhou University, PR-China.

\section{REFERENCES}

[1] Adger, W. N. (2003): Social capital, collective action and adaptation to climate change. Economic Geography 79(4): 387-404.

[2] Adger, W. N. (2006): Vulnerability. - Global Environmental Change 16(3): 268-281.

[3] Adger, W. N., Huq, S., Brown, K., Conway, D., Hulme, M. (2003): Adaptation to climate change in the developing world. - Progress in Development Studies 3(3): 179-195.

[4] Apata, T. G., Samuel, K. D., Adeola, A. O. (2009): Analysis of climate change perception and adaptation among Arable Food Crop farmers in south western Nigeria. International Association of Agricultural Economists' 2009 Conference, Beijing, China. 
[5] Asrat, P., Simane, B. (2018): Farmers' perception of climate change and adaptation strategies in the Dabus watershed, North-West Ethiopia. - Journal of Ecological Processes 7: 7.

[6] Below, T. B., Mutabazi, K. D., Kirschke, D., Franke, C., Sieber, S., Siebert, R., Tscherning, K. (2012): Can farmers' adaptation to climate change be explained by socioeconomic household- level variables? - Global Environmental Change 22(1): 223-235.

[7] Bryan, E., Deressa, T. T., Gbetibouo, G. A., Ringler, C. (2009): Adaptation to climate change in Ethiopia and South Africa: options and constraints. - Environmental Science \& Policy 12(4): 413-426.

[8] Cui, X. F., Graf, H. F. (2009): Recent land cover changes on the Tibetan Plateau: A Review. - Climatic Change 94(1-2): 47-61.

[9] Curwood, P. D., Eckerle, S. (2009): What is poverty? - Esurio: Journal of Hunger and Poverty 1(2): 9-17.

[10] Deressa, T. T., Hassan, R. M., Ringler, C., Alemu, T., Yesuf, M. (2009): Determinants for farmers' choice of adaptation methods to climate change in the Nile Basin of Ethiopia. - Global Environmental Change 19: 248-255.

[11] Dutcher, D. D., Finley, J. C., Luloff, A. E., Johnson, J. (2004): Landowner perceptions ofprotecting and establishing riparian forests: a qualitative analysis. - Society \& Natural Resources 17: 329-342.

[12] Field, A. (2009): Discovering Statistics Using SPSS, Third Ed. - Sage, London.

[13] Francisco, H., Nabangchang, O., Bui, D. T., Yusuf, A. A. (2008): Climate change: impacts, adaptation, and policy in Southeast Asia. - Proceedings of EEPSEA Conference, 13-15 February 2008, Bali, Indonesia.

[14] Frye, I. (2008): What is Poverty? A Qualitative Reflection of People's Experiences of Poverty. - National Labor and Economic Development Institute, Johannesburg, South Africa.

[15] Fu, Y., Grumbine, R. E., Wilkes, A., Wang, Y., Xu, J. C., Yang, Y. P. (2012): Climate change adaptation among Tibetan pastoralists: challenges in enhancing local adaptation through policy support. - Environmental Management 50(4): 607-621.

[16] Gallopín, G. C. (2006): Linkages between vulnerability, resilience, and adaptive capacity. - Global Environmental Change 16(3): 293-303.

[17] Hassan, R., Nhemachena, C. (2008): Determinants of African farmers' strategies for adapting to climate change: multinomial choice analysis. - African Journal of Agricultural and Resource Economics 2(1): 83-104.

[18] Hulme, D., Shepherd, A. (2003): Conceptualizing chronic poverty. - World Development 31(3): 403-423.

[19] Hyland, J. J., Barnes, A., Parkhill, K., Jones, D. L., Williams, A. P. (2016): Farmers' perceptions of climate change: identifying types. - Agric. Hum. Values 33: 323-339.

[20] IPCC (2014): Climate Change 2014: Impacts, Adaptation, and Vulnerability. Part A: Global and Sectoral Aspects. - In: Field, C. B. et al. (eds.) Contribution of Working Group II to the Fifth Assessment Report of the Intergovernmental Panel on Climate Change. Cambridge University Press, Cambridge, UK. http://www.ipcc.ch/report/ar5/wg2.

[21] Intergovernmental Panel on Climate Change (IPCC) (2001): Climate Change 2001: Impacts, Adaptation and Vulnerability. - Cambridge University Press, Cambridge, UK.

[22] Intergovernmental Panel on Climate Change (2007): Regional Climate Projections. - In: Solomon, S., Qin, D., Manning, M., Chen, Z., Marquis, M. et al. (eds) Climate change (2007): the physical science basis. Contribution of Working Group I to the Fourth Assessment Report of the Intergovernmental Panel on Climate Change. Cambridge University Press, Cambridge, UK, pp. 879-886.

[23] IUCN (2010): Building Climate Change Resilience for African Livestock in Sub-Saharan Africa. - The International Union for Conservation of Nature, Eastern and Southern Africa Regional Office, Nairobi. 
[24] Kandji, S. T., Verchot, L., Mackensen, J. (2006): Climate Change and Variability in the SahelRegion: Impacts and Adaptation Strategies in the Agricultural Sector. UNEP/ICRAF, Nairobi, Kenya.

[25] Lasco, R. D., Espaldon, M. L. O. Habito, C. M. D. (2015): Smallholder farmers' perceptions of climate change and the roles of trees and agroforestry in climate risk adaptation: evidence from Bohol, Philippines. - Agroforest Systems 90(3): 521-540. DOI: 10.1007/s10457-015-9874-y.

[26] Lema, M. A., Majule, A. E. (2009): Impacts of climate change, variability and adaptation strategies on agriculture in semi-arid areas of Tanzania: the case of Manyoni District in Singida Region, Tanzania. - African Journal of Environmental Science and Technology 3(8): 206-218.

[27] Li, C. L., Kang, S. C. (2006): Review of studies in climate change over the Tibetan Plateau (in Chinese). - ActaGeographicaSinica 61(3): 327-335.

[28] Liu, X. D., Chen, B. D. (2000): Climatic warming in the Tibetan Plateau during recent decades. - International Journal of Climatology 20(14): 1729-1742.

[29] Leiserowitz, A. (2007): Communicating the Risks of Global Warming: American Risk Perceptions, Affective Images, and Interpretive Communities. - In: Moser, S. C., Dilling, L. (eds.) Creating a Climate for Change: Communicating Climate Change and Facilitating Social Change. Cambridge University Press, Cambridge, pp. 44-63.

[30] Malonine, C. (2006): Les Liens Famille-Troupeau du Ferlo (Sénégal): Témoins de la Dynamique des Systèmesd' Elevage Pastoraux. - Doctoral Thesis. Université Claude Bernard deLyon (Médecine-Pharmacie).

[31] Miller, D. J. (2002): The importance of China's nomads. - Rangelands 24(1): 22-24.

[32] Niu, T., Chen, L. X., Zhou, Z. J. (2004): The characteristics of climate change over the Tibetan Plateau in the last 40 years and the detection of climatic jumps. - Advances in Atmospheric Sciences 21(2): 193-203.

[33] Nori, M., Davies, J. (2007): Change of Wind or Wind of Change? Climate Change, Adaptation and Pastoralism. The World Initiative for Sustainable Pastoralism. International Union for Conservation of Nature, Nairobi, Kenya.

[34] Nyong, A., Adesina, F., Elasha, B. O. (2007): The value of indigenous knowledge in climate change mitigation and adaptation strategies in the African Sahel. - Mitigation and Adaptation Strategies for Global Change12: 787-797.

[35] Sen, A. (1999): Development as Freedom. - Oxford University Press, Oxford, UK.

[36] Seo, S. N., Mendelsohn, R. (2008a): An analysis of crop choice: adapting to climate change in South American farms. - Ecological Economics 67(1): 109-116.

[37] Seo, S. N., Mendelsohn, R. (2008b): Measuring impacts and adaptations to climate change: a structural Ricardian model of African livestock management. - Agricultural Economics 38(2): 151-165.

[38] Smit, B., Wandel, J. (2006): Adaptation, adaptive capacity and vulnerability. - Global Environmental Change 16(3): 282-292.

[39] Smit, B., Burton, I., Klein, R. J. T., Street, R. (1999): The science of adaptation: a framework for assessment. - Mitigation and Adaptation Strategies for Global Change 4(3): 199-213.

[40] Tanner, T., Mitchell, T. (2008): Entrenchment or enhancement: could climate change adaptation help to reduce chronic poverty? - IDS Bulletin 39(4).

[41] Thomas, R. J. (2008): Opportunities to reduce the vulnerability of dryland farmers in Central and West Asia and North Africa to climate change. - Agriculture, Ecosystems and Environment 126: 36-45.

[42] Whelan, C. T. (2007): Measuring consistent poverty in Ireland. - The Economic \& Social Review 38(2): 211-234.

[43] Wongtschowski, M., Verburg, M., Waters-Bayer, A. (2009): What can local innovation contribute to adaptation to climate change? - Paper presented and discussed at the

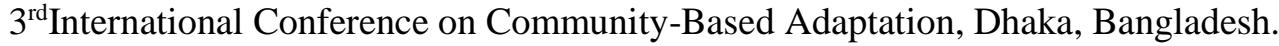


[44] Xiaopen, P., Degang, Z., Changlin, X., Jiangang, C. (2000): The economic comparison on yak production in two types of cold season grassland in Tianzhu, China. - Proceedings of the Third International Congress on Yak Held in Lhasa, P. R. China.

[45] Xu, Z. X., Gong, T. L., Li, J. Y. (2008): Decadal trend of climate in the Tibetan Plateau: regional temperature and precipitation. - Hydrological Process 22(16): 3056-3065.

[46] Zampaligré, N., Dossa, L. H., Schlecht, E. (2013): Climate Change and Variability: Perception and Adaptation Strategies of Pastoralists and Agro-pastoralists across different Zones of Burkina Faso. - Regional Environmental Change 13(5): 18-38.

[47] Zheng, D., Lin, Z. Y., Zhang, X. Q. (2002): Progress in studies of Tibetan Plateau and global environmental change (in Chinese). - Earth Science Frontiers 9(1): 95-102.

\section{APPENDIX}

Questionnaire household

\section{CLIMATE CHANGE PERCEPTIONS AND ADAPTIVE ACTIONS BY PASTORAL COMMUNITY ON THE TIBETAN PLATEAU, CHINA}
Name of Village
Number of Households
Community Name
Population

I. 1. Name of interviewer:

2. Date:

3. Location

\section{INTERVIEWEE INFORMATION}

4. Name: Ethnicity Sex: Male ( ) Female ( ) Age:

5. Education level (Iitterate, primary, secondary, higher secondary, university level)

6. Size of Family: Male ( ), Female ( ) Village Name:

7. Occupation:

Pastoralist ( ) Farm Income () Private Services ( )

Government Services ( )Business ( ) Day Laborer ( )

\section{CLIMATE CHANGE PERCEPTION}

8. Do you know about climate change? Yes () No ()

9. If yes How did you know about climate Change issues?
a. Personal Observation and experience
b. From Government Departments
c. Others sources

10. Is there any impact of climate change on pasture resources and you economic conditions? Yes () No ()

11. If Yes describe

12. Do you own land? Yes ( ) No ( )

\section{LIVESTOCK INFORMATION}

13. What are livestock resource do you have? 


\section{Livestock resources}

\begin{tabular}{|c|l|l|l|l|}
\hline \multirow{2}{*}{ Type of live stock } & \multirow{2}{*}{ Number } & \multicolumn{3}{|c|}{ Feeding Type } \\
\cline { 3 - 5 } & & Open Grazing & Stall feeding & Both \\
\hline Yak & & & & \\
\hline Sheep & & & & \\
\hline Goat & & & & \\
\hline Other & & & & \\
\hline
\end{tabular}

V. PASTURE INFORMATION

14. Do you own on pasture for livestock grazing? Yes ( ) No.( )

15. What type of Pasture? a) Natural b) Artificial

16. On average, how far do the individuals in the community live from the pasture? a. $>1 \mathrm{~km}$ () b. $1-5 \mathrm{~km}($ )c. $<5 \mathrm{~km}($ )

\section{NATURAL ENVIRONMENT}

17. Have you experienced any changes or deviation in weather parameters over the past 20 Years? Yes ( ) No ( )

18. If yes what are negative impacts of climate change on grasslands, livestock etc?

\section{ADOPTION MEASURES}

19. Have you adopted any of the following additional techniques?

\begin{tabular}{|c|l|l|l|}
\hline Techniques & Yes & No & Reasons \\
\hline Changing of crop/tree species & & & \\
\hline Irrigation practices/Water Harvesting Techniques & & & \\
\hline Mix cropping/cultivation of forage & & & \\
\hline Changing from crops to livestock & & & \\
\hline Sowing of good quality seeds & & & \\
\hline Fencing of grassland & & & \\
\hline Controlled grazing & & & \\
\hline
\end{tabular}

\section{INSTITUTIONAL SETUP}

20. Are there any local organizations for

Water management ( ) Pasture management ( ) Agriculture management ( )

Agricultural credits ( ) Disaster relief and rescue ( )

Other organizations (please specify)

21. What do you expect/ what should local government do for adopt of CC impact? 